\title{
Landfill Problems and solutions in Latvia
}

\author{
Ilze Donina \\ Ministry of Environmental Protection \\ and Regional Development
}

Latvia

\begin{abstract}
This paper describes existing situation of landfilling of waste in Latvia, including historical overview of waste disposal in Latvia, institutional set-up, existing waste disposal situation, dumpsite management, environmental impacts of disposal sites. A short description of municipal solid waste management is provided in this paper, in order to characterise possible solutions for waste landfilling problems in Latvia.
\end{abstract}

\section{INTRODUCTION}

Waste management is recognised as one of the priority problems in environmental protection policy of Latvia [1.]. Hazardous waste management system is under development now. The national strategy for municipal solid waste management in Latvia is drafted. Waste disposal sites could be recognised as one of most important components of waste management chain.

\section{OVERVIEW OF THE HISTORY OF WASTE DISPOSAL IN LATVIA.}

Till the end of the 80's waste disposal in Latvia was not considered a serious issue. Decisions on dumpsite locations were taken without site investigations or assessment of possible impacts on the environment. As a rule, only two main considerations determined a decision:

- land not suitable for other purposes can be used as dumping ground;

- dumpsites should not cause (too much) nuisance for local inhabitants.

As a result, the major part of Latvia's dumpsites are situated in old quarries or in wetlands and bogs. In general, dumps are located far from populated areas.[6.] 
As a rule dumping was started without any environmental protection measures. In a country where almost one half of the geological cross-section consists of sandy deposits, such practise definitely would have an impact on the environment.

During the period 1960-1985, industrial activities grew rapidly and many 'dirty' industries were started (metal works, including plating with $\mathrm{Cr}, \mathrm{Ni}, \mathrm{Zn}, \mathrm{Cu}$; pharmaceutical industry, leather processing and other plants). The produced hazardous waste were disposed of in so-called 'landfills for solid household waste'a Authorities did not provide alternative nor set guidelines. Till now, this practice has not changed.

It should be emphasised that the current Government understands and supports activities carried out in order to improve, as far as possible, the existing situation. The first step will be the collection of residues of old pesticides and transfer to the safe storage place.

\section{INSTITUTIONAL SET-UP}

According to the law 'On Self-governments'[2.] and the regulations 'On Physical Planning'[3.] the districts are responsible for the siting of disposal sites. However, in practice the municipalities organise and execute the realisation of the dumpsites. In some cases, the municipalities just start to use an old quarry or a lot of waste land for disposal purposes. In other cases, a permit for site is requested from the regional Environmental Boards or the Environmental Health Centre. In most of these cases, the permit has been issued without serious problem.

\section{THE EXISTING WASTE DISPOSAL SITUATION}

At present, almost each municipality in Latvia, from the largest city to the smallest municipality, exploits its own dumpsite. As a result, 558 known dumps are in operation in Latvia. Considering the enormous differences in the number of inhabitants in each of the 568 municipalities, from few hundred to over 0.8 million, the dumpsites are very diverse as well. Most are rather small, a surface area of less than one hectare and a total waste volume of some 100 to 1.000 cubic metres. These dumps receive only some tens to a couple of hundred cubic metres (up to several tens of tons) of waste per year. The dumps of large cities can be as large as 16 hectares or even 35 hectares and can contain a waste volume up to $3.000 .000 \mathrm{~m}^{3}$ and more, receiving over 1.5 million $\mathrm{m}^{3}$ of waste per year. In addition to the 558 official and more or less official sites, numerous unofficial sites have come to the existence the last few years [5.].

The large majority of dumps $(77 \%)$ is smaller than 2 hectares, while a similar majority $(75 \%)$ receives less than $1.000 \mathrm{~m}^{3}$ per year. In most districts one or two major dumps are present. The remaining dumps are almost of no significance. At the major dumps, $80-90 \%$ of the total waste amount is disposed of. It can be concluded that almost $90 \%$ of all waste brought to dumpsites in Latvia is dis- 
posed of at only 48 sites. In other words, 510 dumps (91\% of total number) receive only $\%$ of the waste to be disposed of on a yearly basis [6.].

\section{DUMPSITE MANAGEMENT}

The composition of the waste dumped at sites in Latvia is for the larger part unknown. However, since the dumping of waste is not (properly) controlled, hazardous waste is often dumped at the sites in addition to municipal solid wastes.

At a large majority of the sites in Latvia, no real environmental protection measures have been taken although at many of the larger sites, some kind of dumpsite management is in operation. Dumpsite management actions vary from compacting of waste every few month to, at large sites, compacting on daily basis by means of a bulldozer, in combination with several other landfill management activities like landscaping, landfill road construction, inspection and supervision on dumping practices, etc [6.].

After compacting, the waste is covered with soil in some cases, definitely not at every site. Cover material is mined in at site and/or brought to the site from elsewhere. At most large sites, a guard is present during the day time.

At a number of sites, people are involved in secondary recovery of recyclable materials. Waste is sorted manually, in some cases by dumpsite personnel, in other cases by scavengers.

\section{ENVIRONMENTAL IMPACTS}

\section{Impacts on soil and groundwater's}

The main reason for soil and groundwater contamination is that in the Latvian situation many dumpsites are located in former sand and gravel quarries or directly on the sand layer without environmental protection measures. In combination with a precipitation surplus of approximately $200 \mathrm{~mm}$ per year, impacts on soil and groundwater are caused in all of these cases. The extent of the impacts mainly depends on the composition of the waste disposed of. As a result of the groundwater contamination, drinking water is contaminated as well. The drinking water for the major part of Latvia's inhabitants is obtained from groundwater aquifers.

For some sites, information is available on the impacts on the groundwater quality. Especially around the largest dumps, in operation close to the large cities and towns, ground water quality surveys were carried out. In most cases, however, no investigations of the groundwater has been conducted [6.]. 


\section{Impacts on surface waters}

Since most dumpsites are not located in the direct vicinity of surface water bodies, the impacts on surface water are limited. In most cases, no investigations of surface water quality have been conducted. In view of a yearly precipitation of approximately of $660 \mathrm{~mm}$ per year, the precipitation surplus and the limited number of days with precipitation (approximately 120), large amount of run-off are to be expected. In combination with the absence of top covers on dumpsites, impact on surface waters are eminent.

\section{Impacts on air}

Since at most dumpsites due care is taken to prevent fire, the impacts of dumps on the air quality is limited to the emission of landfill gas and odours. The remote location of most sites warrants limited impact by odours. In optimum conditions for landfill gas production, a peak production rate of several hundreds cubic metres of gas per hour might be expected at each of the major sites in Latvia. At small sites, landfill gas production is limited. Landfill gas consists for the larger part of methane and carbon dioxide. Both compounds are greenhouse gases contributing to the climate change. Local impacts of the emission of landfill gas is limited to an increase of risk of fires and (in case of building constructed at the dumpsite) explosions and damage, including dying of the flora near the dumpsite [6.].

\section{Other impacts}

Other impacts include deterioration of landscape, noise, direct and indirect impacts on flora and fauna and fragmentation of habitats. These impacts are very site specific. However, since most dumpsites are rather small, the impacts of these sites are limited [6.].

\section{POSSIBLE SOLUTIONS TO THE LANDFILLING PROBLEMS IN LATVIA}

In order to improve waste management service and to provide it to all inhabitants of Latvia, a municipal solid waste management strategy is elaborated with support of Ministry of Environmental protection and Regional Development. The strategy is aiming at improvement of waste management services and to increase number of population serviced. The most important goal of the strategy is to decrease negative impact of waste. Today it is complicated to decrease environmental impact due to the big number of waste disposal sites. Preliminary economical calculations has proven that in conditions of Latvia it is necessary to construct landfills which could serve for waste disposal from approximately 150.000 inhabitants. Therefore it is planned to decrease important decrease of number of disposal sites, taking into consideration closure of disposal sites and construction of new sanitary landfills. In the far future it is planned to pay more 
attention to the waste minimisation and reduction, promotion of waste recycling and recovery [4.].

In order to implement solid waste management strategy, it is necessary to create necessary legal and institutional requirements for improvement of solid waste management strategy, in order to improve involvement of municipalities and population in municipal solid waste management. It is planned to start a pilot project with development of intermunicipal solid waste management organisation for all municipalities of pilot area. This co-operation would allow to decrease necessary investments per each inhabitant and to increase number of inhabitants serviced by waste management company. It is planned to prepare local by-laws and guidelines; to develop and to approve system of tariffs; to construct a sanitary sanitary landfill, to rise a public awareness [4.].

The national municipal solid waste management strategy is a basis for investment programme " 500-"(National solid waste management strategy).

The implementation of such a project is connected with considerable amount of investments. The principle of co-financing will be applied for implementation of projects in municipal solid waste management. In another investment programme ' $800+$ '(Water supply and waste water treatment plants in towns of Latvia) a following co-financing scheme was applied successfully - 30\% from state budget, $30 \%$ - grants, $30 \%$ - loans, $10 \%$ - budget of municipalities. It is planned to apply this scheme also for financing of solid waste management projects.

\section{CONCLUSIONS}

Planning of the number of and locations for dumpsites is practically non-existent in Latvia. Site selection criteria are limited to the availability of land not suitable for other purposes.

In practice each municipality deals with waste disposal itself. As a result there are 558 operational dumps in Latvia.

Most dumps are rather small and/or receive only a small amount of waste per year.

At most sites, dumpsite management is limited to levelling of waste once or twice a year. At some of the large sites, management includes regular levelling and compacting and occasional covering of waste. Environmental protection measures have not been taken at any site, although at some sites groundwater monitoring systems have been installed.

None of the sites in Latvia can be classified as sanitary landfills. Therefore none of the sites comply with the EU standards for landfills.

It is obvious that most sites cause negative impacts on the environment. To a large extent, the actual damage caused is not known. Only in some cases, groundwater and surface water investigations have been carried out. 


\section{REFERENCES}

1. Ministry of Environmental Protection and regional Development (1995). National Environmental Policy Plan for Latvia, 1995

2. Law of Republic of Latvia 'On municipalities'(1994)

3. Regulations of Cabinet of Ministers of Republic of Latvia'On Physical Planning'(1994)

4. Carl Bro als (1997). National Municipal Solid Waste Strategy ,Latvia (draft)

5. Carl Bro als (1997). Report on Current Municipal Solid Waste Management System

6. Carl Bro als (1997) Report on Existing Dumpsites. 